\title{
Cultivation of Yeast in Medium Containing Liquid from Fish Waste Juice*1
}

\author{
Md. Abul Hossain, ${ }^{* 2}$ Masayuki Furuichi, ${ }^{* 2}$ and Yasuo Yone ${ }^{* 2}$ \\ (Accepted November 24, 1987)
}

\begin{abstract}
Attempts were made to examine whether the liquid obtained from the mackerel waste juice could be utilized as a nutrient source by yeast or not. Yeast, Saccharomyces serevisiae IFO 2114, grew sufficiently in $75 \%$ sea water containing $2.5 \%$ liquid. Moreover, $1 \%$ glucose or molasses added as a carbon source into the culture medium accelerated growth of the yeast. The stationary phase was observed after $30 \mathrm{~h}$ from beginning of the yeast culture. The nitrogen and phosphorus contents in the culture medium decreased with the yeast growth. These results indicate the possibility of a large scale cul!ure for yeast by use of the liquid prepared from fish waste juice.
\end{abstract}

Previous studies on the utilization of fish waste demonstrated that the scrap meal prepared from fish waste was useful as fish feed rich in a protein and lipid by application of the microbial function. ${ }^{1-4)}$ However, in the process of manufacturing of scrap meal from fish waste, a considerable amount of pressed juice is produced. The fish waste juice contains lipids, water soluble substances such as nitrogenous and phosphorus compounds, and sediments. If it is thrown away without proper treatment, it may become a source of environmental pollution. Accordingly, it is necessary to find out a suitable way to utilize the pressed waste juice.

In the present study, the liquid which contains water soluble substances was separated from the fish waste juice, and it was investigated whether the liquid could be utilized as a nutrient source by yeast or not.

\section{Materials and Methods}

\section{Experiment I}

Experiment I was conducted to examine the optimum levels of liquid and glucose added into a culture medium.

1. Liquid. Liquid was obtained by centrifuging the juice pressed out from mackerel waste at $2,000 \mathrm{rpm}$ for $15 \mathrm{~min}$ and stored in a refrigerator.

2. Yeast Seed. Saccharomyces cerevisiae IFO 2114 cultured on a MY agar slant medium ${ }^{5)}$ was inoculated into $20 \mathrm{ml} \mathrm{MY}$ broth medium in a $100 \mathrm{~m} /$ test tube and cultured at $28-30^{\circ} \mathrm{C}$ for $36 \mathrm{~h}$ by shaking in a water bath with reciprocal shaker.

3. Culture Media. Thirty nine test tubes of $100 \mathrm{~m} /$ capacity were divided into 3 groups with 13 each. To each test tube of the first group, $0.5 \mathrm{~g}$ glucose was added and $1.0 \mathrm{~g}$ glucose was added to each of the second group. No glucose was added to that of the third group. Then, from 0 to $3.0 \mathrm{ml}$ of the liquid with a cumulative increase of $0.25 \mathrm{~m} /$ was added to each test tube of 3 groups. The volume of medium in each test tube of 3 groups was adjusted exactly to $50 \mathrm{~m} l$ by addition of the required amount of $75 \%$ sea water and sterilized.

4. Propagation. The yeast seed was inoculated to each medium at a rate of 5 million cells per $\mathrm{m} l$ and cultured at $28-30^{\circ} \mathrm{C}$ for $36 \mathrm{~h}$ by shaking. After the culture, the test tubes were stored immediately in a refrigerator until the yeast cells were counted by a hemacytometer. Before counting, the test tubes containing the yeast cultured were violently shaked to make a homogeneous distribution of cells in the medium.

\section{Experiment II}

In experiment II, The cultivation time for the best growth of the yeast was examined. The forty test tubes of $100 \mathrm{ml}$ capacity were divided into 5 groups, and $50 \mathrm{ml}$ of medium was added into each test tube and then sterilized. These media employed were $75 \%$ sea water containing

*1. Contribution from Fish. Res. Lab., Kyushu University, No. 173. Studies on Utilization of Fish Waste7.

*2 Fishery Research Laboratory, Kyushu University, Tsuyazaki, Fukuoka 811-33, Japan (モハメドアブル 木セイン，古市政幸，米 康夫：九州大学農学部附属水産実験所). 
Table 1. Growth of the yeast, Saccharomyces cerevisiae cultured in $75 \%$ sea water containing liquid from fish waste juice and glucose

\begin{tabular}{cccc}
\hline \multirow{2}{*}{$\begin{array}{c}\text { Conc. } \\
\text { of liquid } \\
(\%)\end{array}$} & 0 & $\begin{array}{c}\text { Conc. of glucose }(\%) \\
1.0\end{array}$ & 2.0 \\
\cline { 2 - 4 } & $\begin{array}{c}\times 10^{\circ} \\
\text { cells } / \mathrm{m} l\end{array}$ & $\begin{array}{c}\times 10^{\circ} \\
\text { cells } / \mathrm{m} l\end{array}$ & $\begin{array}{c}\times 10^{\circ} \\
\text { cells } / \mathrm{m} l\end{array}$ \\
\hline 0 & 9.2 & 20.8 & 26.4 \\
0.5 & 16.2 & 30.6 & 42.1 \\
1.0 & 15.4 & 42.2 & 52.8 \\
1.5 & 20.4 & 61.1 & 71.6 \\
2.0 & 23.3 & 65.3 & 93.5 \\
2.5 & 27.2 & 84.4 & 106.6 \\
3.0 & 24.5 & 79.3 & 92.5 \\
3.5 & 25.2 & 78.8 & 87.2 \\
4.0 & 28.6 & 78.4 & 95.2 \\
4.5 & 31.0 & 87.2 & 96.0 \\
5.0 & 23.4 & 79.0 & 92.2 \\
5.5 & 19.6 & 54.8 & 104.8 \\
6.0 & 17.2 & 37.2 & 82.3 \\
\hline
\end{tabular}

1.0 or $2.0 \%$ glucose, and $75 \%$ sea water containing $2.5 \%$ liquid with and without 1.0 or $2.0 \%$ glucose, respectively. The test tubes were set in a water bath for shaking culture, and one test tube from each group was taken out at $6 \mathrm{~h}$ intervals. The preparations of the liquid and yeast seed, and the methods of incubation, propagation and cell counting were the same as described in experiment $I$.

\section{Experiment III}

The effect of molasses added in place of glucose into the medium on growth of the yeast was investigated in this experiment. Furthermore, the changes of nitrogen and phosphorus levels in the medium during the culture were examined. Two flasks of $3 l$ capacity were used. The media $(1.5 l)$ were $75 \%$ sea water containing $2.5 \%$ liquid, and $75 \%$ sea water containing $2.5 \%$ liquid and $1.0 \%$ molasses. The preparations of the liquid and yeast seed, and the methods of incubation, propagation and cell counting were the identical to those in experiment $\mathrm{I}$. The cultivation was continued for $48 \mathrm{~h}$ and the sampling was done at $6 \mathrm{~h}$ intervals.

\section{Analytical Methods}

Total nitrogen and total phosphorus in the medium were estimated by modified Kjeldahl method, ${ }^{8)}$ and by Hansen and Robinson method, ${ }^{7}$ respectively, after removal of the yeast cell by filter.

\section{Results and Discussion}

As shown in Table 1, the yeast grew in proportion to the concentration of the liquid in the culture medium and the maximum growth was observed at $2.5 \%$ level of the liquid. Furthermore, supplemented glucose at a level of 1.0 or $2.0 \%$ in the medium accelerated growth of the yeast.

Table 2 shows the relationship between the yeast growth and the cultivation time. The stationary phase during a culture of the yeast was observed after $30 \mathrm{~h}$ in each medium. A combination of the liquid and glucose yielded better growth than in the case of the liquid or the glucose only.

The replacement of glucose by molasses did not almost have an adverse infiuence on growth of the yeast, as shown in Fig. 1. The nitrogen and phosphorus contents in the medium gradually decreased with the yeast growth. This result indicates that the yeast utilized the nitrogen and phosphorus in the medium as nutrient sources for its growth.

Contents of nitrogen and phosphorus in the

Tnble 2. Cultivation time and growth of the yeast in various media

\begin{tabular}{ccccccc}
\hline \hline \multirow{2}{*}{$\begin{array}{c}\text { Time of } \\
\text { culture } \\
(\mathrm{h})\end{array}$} & \multicolumn{2}{c}{ Without liquid } & & \multicolumn{3}{c}{$2.5 \%$ liquid } \\
\cline { 2 - 3 } \cline { 6 - 7 } \cline { 5 - 6 } & $\begin{array}{c}1 \% \text { glucose } \\
\times 10^{8} \text { cells } / \mathrm{m} l\end{array}$ & $\begin{array}{c}2 \% \text { glucose } \\
\times 10^{8} \text { cells } / \mathrm{m} l\end{array}$ & & $\begin{array}{c}\text { without } \\
\text { glucose } \\
\times 10^{8} \text { cells } / \mathrm{m} l\end{array}$ & $\begin{array}{c}1 \% \text { glucose } \\
\times 10^{8} \text { cells } / \mathrm{m} l\end{array}$ & $\begin{array}{c}2 \% \% \text { glucose } \\
\times 10^{8} \text { cells } / \mathrm{m} l\end{array}$ \\
\hline 0 & 5.0 & 5.0 & & 5.0 & 5.0 & 5.0 \\
6 & 7.3 & 7.7 & & 6.1 & 10.7 & 9.8 \\
12 & 12.7 & 15.1 & & 10.8 & 26.3 & 24.2 \\
18 & 20.7 & 22.2 & & 18.0 & 40.7 & 49.6 \\
24 & 22.4 & 27.4 & & 24.3 & 62.3 & 71.1 \\
30 & 24.9 & 30.1 & & 27.5 & 65.1 & 82.3 \\
36 & 24.1 & 30.4 & & 27.1 & 67.4 & 87.0 \\
42 & 23.6 & 28.9 & & 27.8 & 69.4 & 85.2 \\
48 & 23.3 & 29.4 & 27.4 & 60.1 & 83.0 \\
\hline
\end{tabular}




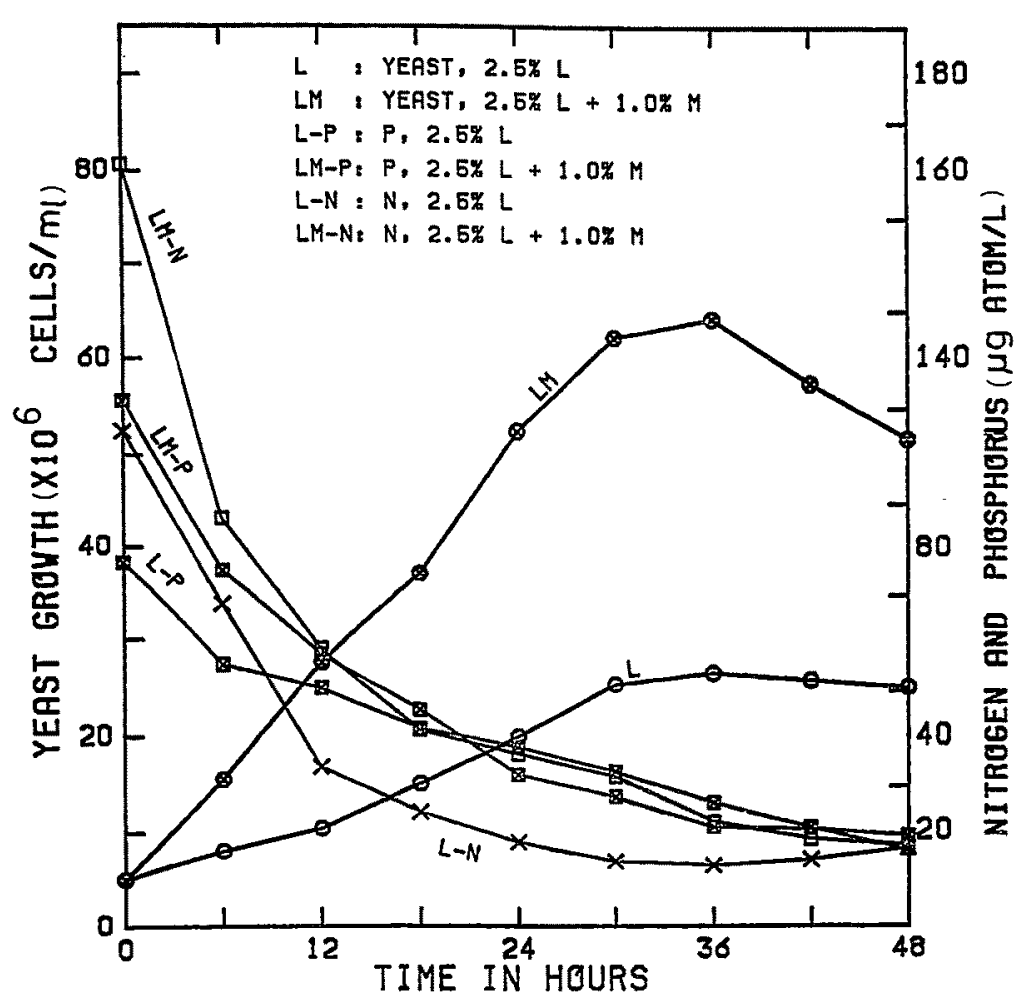

Fig. 1. Relationship between population growth of the yeast and phosphorus or nitrogen level in the culture media.

medium after 36 hours' cultivation are considered to be a safety level enough to discard without pretreatment.

From these findings, it was found that Sacch. cerevisiae IFO 2114 showed the good growth, when cultured in diluted sea water containing $2.5 \%$ liquid from fish waste juice and $1.0 \%$ molasses for $36 \mathrm{~h}$ at 28 to $30^{\circ} \mathrm{C}$. The results obtained from the present study also suggest the possibility of a large scale culture for yeast by use of liquid from fish waste juice.

\section{References}

1) Y. Yone, M. A. Hossain, M. Furuichi, and F. Kato: Nippon Suisan Gakkaishi, 52, 549-552 (1986).
2) Y. Yone, M. A. Hossain, M. Furuichi, and F. Kato: Nippon Suisan Gakkaishi, 52, 1461-1464 (1986).

3) M. A. Hossain, M. Furuichi, and Y. Yone: Nippon Suisan Gakkaishi, 53, 1629-1632 (1987).

4) M. A. Hossain, M. Furuichi, and Y. Yone: Nippon Suisan Gakkaishi, 53, 1669-1671 (1987).

5) F. Kato, I. Nakazato, T. Shiraishi, K. Hayashi, A. Murata, and Y. Yone: Nippon Nōgeikagaku Kaishi, 59, 901-907 (1985).

6) J. Kjeldahl: in "A practical handbook of sea water analysis" (ed. by D. H. Strickland and T. R. Parsons), Fish. Res. Board Canada, Bull. 167, Ottawa, 1972, pp. 143-147.

7) Hansen and Robinson: in "A practical handbook of sea water analysis" (ed. by D. H. Strickland and T. R. Parsons), Fish. Res. Board Canada, Bull. 167, Ottawa, 1972, pp. 57-61. 